\title{
Cytogenetic analysis of B-cell posttransplant lymphoproliferations validates the World Health Organization classification and suggests inclusion of florid follicular hyperplasia as a precursor lesion
}

\author{
Efsevia Vakiani MD, PhD, Subhadra V. Nandula PhD, \\ Shivakumar Subramaniyam PhD, Christian E. Keller MD, \\ Bachir Alobeid MD, Vundavalli V. Murty PhD, Govind Bhagat MD*
}

Department of Pathology, College of Physicians and Surgeons, Columbia University, New York, NY 10032, USA

Received 18 May 2006; revised 9 August 2006; accepted 14 August 2006

Keywords:
Posttransplant;
Lymphoproliferative
disorder;
Florid follicular
hyperplasia;
Karyotype;
Phenotype

* Corresponding author.

E-mail address: gb96@columbia.edu (G. Bhagat).

\begin{abstract}
Summary Cytogenetic abnormalities in B-cell posttransplant lymphoproliferative disorders (PTLD) have not been well characterized. We thus performed cytogenetic analysis of 28 cases of B-cell PTLD, 1 infectious mononucleosis (IM)-like lesion, 9 polymorphic PTLD, 17 monomorphic PTLD, and 1 classical Hodgkin lymphoma (HL), and correlated the karyotypic findings with the phenotype, EpsteinBarr virus infection status, and clinical outcome. Karyotypes of 19 cases of posttransplant florid follicular hyperplasia (FFH) were also analyzed. Informative karyotypes were obtained in 20 (71.4\%) of 28 PTLDs and $18(94.7 \%)$ of 19 FFHs. Clonal karyotypic abnormalities were detected in 13 (65\%) of 20 PTLDs, including 9 (75\%) of 12 monomorphic PTLDs, 2 (33.3\%) of 6 polymorphic PTLDs, 1 IM-like lesion, and $1 \mathrm{HL}$, and $2(11.1 \%)$ of 18 FFHs. Recurrent chromosome breaks at 1q11-21 $(\mathrm{n}=6$, including $1 \mathrm{FFH})$, $14 \mathrm{q} 32(\mathrm{n}=3$, including $1 \mathrm{FFH}), 16 \mathrm{p} 13(\mathrm{n}=3), 11 \mathrm{q} 23-24(\mathrm{n}=2)$, and 8q24 $(c-M Y C)(\mathrm{n}=2)$; gains of chromosome $7(n=4), X(n=3), 2(n=3), 12(n=2)$; and loss of chromosome $22(n=2$, including 1 IMlike lesion) were identified. The presence of cytogenetic abnormalities did not correlate with PTLD phenotype, Epstein-Barr virus infection, or clinical outcome. We describe novel karyotypic aberrations in PTLD and report clonal cytogenetic abnormalities in posttransplant FFH and an IM-like lesion for the first time. Our findings provide validation of the current World Health Organization classification of PTLD and also suggest incorporation of FFH as the earliest recognizable precursor of PTLD.

(C) 2007 Elsevier Inc. All rights reserved.
\end{abstract}

\section{Introduction}

B-cell posttransplant lymphoproliferative disorders (PTLD) comprise a spectrum of lymphoid proliferations ranging from early lesions, represented by plasma cell hyperplasia (PH) and infectious mononucleosis (IM)-like 
proliferations, which are mostly polyclonal, to monomorphic PTLD (M-PTLD) that are usually monoclonal proliferations of mature B cells or plasma cells [1]. The majority of B-cell PTLD are associated with Epstein-Barr virus (EBV) infection, but EBV-lymphoid proliferations are not uncommon, occurring late after organ transplantation [2].

The current World Health Organization (WHO) classification represents a refinement of the prior classification schemes for PTLD [3-5], although the precursor product relationship between early lesions or polymorphic PTLD (P-PTLD) and distinct subsets of M-PTLD is unclear at present. Recent studies [6,7] have also suggested that adenotonsillar hypertrophy, histologically characterized by florid follicular hyperplasia (FFH), might represent a precursor to PTLD. However, an association of FFH with currently recognizable types of PTLD has not been demonstrated [8] and FFH is not recognized as a precursor lesion in the current WHO classification [1].

Many studies have elucidated the cytogenetic and molecular underpinnings of a variety of B-cell non-Hodgkin lymphomas (B-NHL) occurring in immunocompetent individuals [9-13], but there is limited information regarding genetic alterations in PTLD. Mutations in protooncogenes or tumor suppressor genes, for example, $c-M Y C, N-R A S$, $B C L 6$, and $p 53[4,14]$ have been reported, mostly in M-PTLD, and mutations of BCL6 have been associated with a worse clinical outcome [14]. Aberrant somatic hypermutation leading to mutations of protooncogenes $c-M Y C, P A X 5$, and RhoH/TTF has also recently been described in M-PTLD [15]. Data regarding chromosomal abnormalities in PTLD consist of case reports [16-20] and only 2 recently published series $[21,22]$.

Thus, the aim of our study was to determine the nature and frequency of karyotypic abnormalities in B-cell PTLD and FFH of adenotonsillar, nodal, and extranodal lymphoid tissue diagnosed at our institute over a 9-year period. We also correlated the karyotypic findings with the phenotype of these lymphoproliferations, results of B-cell clonality and EBV infection, and the clinical outcome.

\section{Materials and methods}

\subsection{Case selection and clinical parameters}

We searched our cancer cytogenetics database to retrieve cases of B-cell PTLD and lymphoid tissue showing FFH submitted for karyotype analysis, over a 9-year period (1997-2005). Data regarding immunosuppressive regimens, antiviral capsid antigen IgG (IgG-VCA) titers, polymerase chain reaction (PCR)-based quantification of EBV viral load, and clinical outcomes were obtained from our hospital information system; IgG-VCA titers greater than 1:40 were considered positive and 5-fold or greater increase of EBV viral copies, above the PCR limit of detection (200 copies per milliliter), was considered evidence of viral reactivation.

\subsection{Morphologic and phenotypic characterization}

Posttransplant lymphoproliferative disorders were categorized according to the current WHO classification [1] using hematoxylin and eosin-stained, formalin-fixed, paraffin-embedded sections. In addition, PTLD were defined as having a germinal center (GC) phenotype if they had the profile BCL6+, MUM1-, CD138-, and as post-GC if they were BCL6-, MUM1+, CD138- or BCL6-, MUM1+, CD138+.

\subsection{Immunohistochemistry, in situ hybridization, and flow cytometry}

The panel of primary antibodies used for immunohistochemical staining included CD20, BCL6, MUM1, CD3, CD21, CD138 (DAKO, Carpinteria, Calif), BCL2- (Biogenex, San Ramon, Calif), CD10 (Novocastra, Burlingame, Calif), and $\kappa$ and $\lambda$ (Cell Marque, Hot Springs, Ariz). Staining was performed after moist heat-induced antigen retrieval using an autostainer (Universal Staining System, DAKO) according to standard methods. The Envision Plus kit (DAKO) was used for detection with 3,3' -diaminobenzidine as the chromogen. In situ hybridization for EBVencoded small RNAs (EBER) was performed in all cases using the supplied protocol (INFORM EBER, Ventana, Tucson, Ariz). The frequency of EBER+ cells was scored in a semiquantitative manner by averaging the number of positive cells in 10 random high power fields (HPF).

Three- or 4-color flow cytometric analysis (FACScan; Becton Dickinson, San Diego, Calif) was performed according to standard methods and data analyzed using the Cell Quest software (Becton Dickinson). Antibodies used included CD45, CD19, CD20, CD10, CD3, IgM, IgG, IgA, IgD, $\kappa$, and $\lambda$ (BD Biosciences, San Diego, Calif).

\subsection{Immunoglobulin heavy chain gene rearrangement analysis}

Polymerase chain reaction analyses to detect immunoglobulin heavy chain $(\operatorname{IgH})$ gene rearrangements were performed using DNA extracted from formalin-fixed, paraffin-embedded tissue using consensus primers for the heavy chain framework region 3 and the joining region, followed by polyacrylamide gel electrophoresis after heteroduplex formation, as previously described [23].

\subsection{Giemsa-band karyotype, fluorescence in situ hybridization, and spectral karyotype analysis}

Giemsa banding was performed on metaphase preparations obtained after overnight cell culture (12-15 hours) without mitogen stimulation using standard methods, and the karyotype was described according to ISCN [24]. Fluorescence in situ hybridization (FISH) analyses were performed on methanol-acetic acid fixed cells (14 cases) using IGH ( $\mathrm{n}=12), B C L 6(\mathrm{n}=5), B C L 2(\mathrm{n}=3), M Y C$ $(\mathrm{n}=2)$, and MALT1 $(\mathrm{n}=1)$ dual-color break-apart probes 
(VYSIS, Downers Grove, Ill), according to standard protocol; 200 to 500 cells were analyzed. Fluorescence signals were captured after counterstaining with DAPI using the Cytovision Imaging system attached to a Nikon Eclipse 600 microscope (Applied Imaging, Santa Clara, Calif). Spectral karyotype (SKY) was performed on metaphase preparations using the human SKYPaint kit (Applied Spectral Systems, Carlsbad, Calif) according to the manufacturer's protocol.

\subsection{Statistical analysis}

Fisher exact test and Student $t$ test were performed to evaluate differences between datasets, as applicable, and a $P$ value less than .05 was considered significant.

\section{Results}

\subsection{Clinical characteristics}

Tonsil and/or adenoid $(\mathrm{n}=16)$ and lymph node $(\mathrm{n}=2)$ specimens with FFH from 18 of 19 patients (8 males, 10 females; age, 2-60 years; median, 3.5 years; mean, 8.4 years) had analyzable metaphases. These patients had undergone liver $(\mathrm{n}=15)$, kidney $(\mathrm{n}=1)$, or heart $(\mathrm{n}=2)$ transplantation. The median time from transplant to diagnosis was 35 months (range, 7-96 months; mean, 41.8 months). None of the patients required reduction in immunosuppression or chemotherapy, and 16 of 18 patients are currently alive (range, 2-41 months; median, 14 months; mean, 17.3 months) since diagnosis; 2 were lost to followup. None of the patients developed PTLD after FFH; however, 2 had developed M-PTLD, in the stomach and in tonsils and right cervical lymph node, 2 and 6 years before FFH of tonsils and right cervical lymph node, respectively. Cytogenetic analyses of PTLD were not performed, and specimens with FFH from both patients had normal karyotypes.

Twenty-eight specimens, including nodal $(\mathrm{n}=8)$, extranodal $(\mathrm{n}=15)$, and adenotonsillar tissue $(\mathrm{n}=5)$, from 27 patients with B-cell PTLD, including 1 IM-like lesion, 1 classic Hodgkin lymphoma (HL), 9 P-PTLD, and 17 M-PTLD, were submitted for cytogenetic analysis. Monomorphic PTLD from 2 different sites (obtained 1 week apart) were analyzed for 1 patient (no. 7, Table 1). Analyzable metaphases were obtained in $20(71.4 \%)$ of 28 PTLD involving nodal $(\mathrm{n}=7)$, extranodal $(\mathrm{n}=10)$, and adenotonsillar tissue $(\mathrm{n}=3)$ from 19 patients. One patient had an IM-like lesion (no. 3, Table 1), 6 had P-PTLD (3 males, 3 females; median age, 14 years; mean age, 19.3 years; range, 3-56 years), 11 had M-PTLD (10 males, 1 female; median age, 58 years; mean age, 48.8 years; range, 11-76 years), and 1 had HL (no. 14, Table 1). Patients with P-PTLD had undergone heart $(\mathrm{n}=3)$, liver $(\mathrm{n}=1)$, kidney $(\mathrm{n}=1)$, and lung $(\mathrm{n}=1)$ transplantation, 3 to 144 months previously (median, 14 months; mean, 29.3 months). Treatment consisted of decrease in immunosuppression, either alone $(\mathrm{n}=1)$ or in combination with chemotherapy $(\mathrm{n}=4)$, rituximab $(\mathrm{n}=3)$, and radiation $(\mathrm{n}=1)$. Five $(83.3 \%)$ of 6 patients are currently alive 4 to 103 months (median,

Table 1 Clinical characteristics of patients with cytogenetic abnormalities

\begin{tabular}{|c|c|c|c|c|c|c|c|c|c|}
\hline Patient & Age (y) & Sex & Site & Diagnosis & $\begin{array}{l}\text { EBV } \\
\text { serology } \\
\text { pretransplant }\end{array}$ & $\begin{array}{l}\text { Organ } \\
\text { transplant }\end{array}$ & $\begin{array}{l}\text { Time to } \\
\text { diagnosis } \\
\text { (mo) }\end{array}$ & $\begin{array}{l}\text { Treatment of } \\
\text { PTLD }\end{array}$ & $\begin{array}{l}\text { Outcome } \\
\text { (time) }\end{array}$ \\
\hline 1 & 4 & M & $\begin{array}{l}\text { Tonsils, } \\
\text { adenoids }\end{array}$ & FFH & Positive & Liver & 43 & NA & A (11 mo) \\
\hline 2 & 2 & $\mathrm{~F}$ & Tonsils & FFH & Negative & Liver & 21 & NA & A (41 mo) \\
\hline 3 & 9 & $\mathrm{~F}$ & $\begin{array}{l}\text { Tonsils, } \\
\text { adenoids }\end{array}$ & early lesion IM-like & Positive & Heart & 104 & None & A (12 mo) \\
\hline 4 & 3 & $\mathrm{~F}$ & Lymph node & P-PTLD & Positive & Liver & 35 & DI, CT, rituximab & LTF \\
\hline 5 & 21 & M & Lymph node & P-PTLD & Negative & Kidney & 6 & DI, CT, rituximab & A (4 mo) \\
\hline 6 & 60 & M & Soft tissue & M-PTLD-MZBCL & Positive & Kidney & 96 & DI, rituximab & $\mathrm{D}^{\mathrm{a}}(36 \mathrm{mo})$ \\
\hline $\begin{array}{l}7 \mathrm{a} \\
7 \mathrm{~b}\end{array}$ & 11 & $\mathrm{~F}$ & $\begin{array}{l}\text { Pleural fluid } \\
\text { Lymph node }^{b}\end{array}$ & M-PTLD-DLBCL, c & Negative & Liver & 83 & DI, rituximab & $\mathrm{D}(1 \mathrm{mo})$ \\
\hline 8 & 54 & M & Lymph node & M-PTLD-DLBCL, c & ND & Liver & 177 & $\mathrm{CT}$ & A $(2 \mathrm{mo})$ \\
\hline 9 & 72 & M & Bone marrow & M-PTLD-DLBCL, i & Positive & kidney & 120 & $\mathrm{CT}$ & $\mathrm{D}(18 \mathrm{mo})$ \\
\hline 10 & 64 & M & Pleural fluid & M-PTLD-DLBCL, c & ND & kidney & 54 & $\mathrm{CT}$, rituximab & $\mathrm{D}(18 \mathrm{mo})$ \\
\hline 11 & 76 & M & Nasal mucosa & M-PTLD-DLBCL, p & ND & heart & 144 & DI, RT & A $(35 \mathrm{mo})$ \\
\hline 12 & 25 & M & Cecum & M-PTLD-BL & Negative & kidney & 93 & $\mathrm{CT}$ & A $(6 \mathrm{mo})$ \\
\hline 13 & 15 & M & $\begin{array}{l}\text { Tonsils, } \\
\text { adenoids }\end{array}$ & M-PTLD-PLL & Negative & heart & 143 & $\mathrm{CT}$ & A (2 mo) \\
\hline 14 & 4 & $\mathrm{~F}$ & Lymph node & cHL & Positive & heart & 18 & $\mathrm{CT}$ & $\mathrm{A}(51 \mathrm{mo})$ \\
\hline
\end{tabular}

Abbreviations: c, centroblastic; i, immunoblastic; p, plasmablastic; cHL, classic Hodgkin lymphoma; A, alive; D, dead; ND, not done; NA, not applicable; DI, decreased immunosuppression; CT, chemotherapy; RT, radiation; LTF, lost to follow-up.

${ }^{a}$ Died of gastric cancer.

b Specimens from the same patient obtained 1 week apart. 
40 months; mean, 41 months) after diagnosis, and 1 patient died 6 months postdiagnosis from infectious complications. Patients with M-PTLD had undergone kidney $(\mathrm{n}=6)$, heart $(\mathrm{n}=4)$, and liver $(\mathrm{n}=2)$ transplantation (1 patient received a combined kidney-liver transplant), 3 to 177 months previously (median, 96 months; mean, 96.8 months). Ten patients received chemotherapy, 3 of whom also received rituximab, and 1 was treated with radiation alone. Four $(36.4 \%)$ of 11 patients are alive 2 to 35 months (median, 4 months; mean, 11.3 months) after diagnosis, and 7 patients died from progression of their disease $(n=5)$, sepsis $(n=1)$, or gastric cancer $(\mathrm{n}=1), 1$ to 36 months (median, 4 months; mean, 11.6 months) after diagnosis.

Two patients (nos. 4 and 3, Tables 1 and 2) had adenotonsillar FFH, 11 months and 8 years before diagnosis of PTLD, respectively. One patient (no. 13, Table 1) developed M-PTLD involving tonsils and adenoids, 8.5 years after $\mathrm{PH}$ at the same site. Cytogenetic analyses on specimens with FFH and $\mathrm{PH}$ were not performed.

\subsection{Morphology and phenotype}

All tonsils and adenoids (and 2 lymph nodes) diagnosed as $\mathrm{FFH}$ (Fig. 1A) showed markedly enlarged germinal centers (CD10+, BCL6+, BCL2-) containing numerous tingible-body macrophages and expanded follicular dendritic cell meshworks (CD21+). A variable number of follicles showed blurring of the dark zone-light zone boundary and attenuation or loss of the mantle zones. Interfollicular areas were only mildly expanded by small lymphocytes, scattered immunoblasts, and small clusters of polytypic plasma cells.

The IM-like lesion (Fig. 1D) showed large secondary follicles similar to those observed in FFH and a moderate to marked interfollicular expansion due to increased numbers of polytypic plasma cells, small lymphocytes, histiocytes, and scattered or small clusters of immunoblasts. Diffuse polytypic plasma cell infiltrates with absent or rare reactive follicles were diagnosed as PH. P-PTLD (Fig. 1F) showed scattered or small clusters of large centroblasts or immunoblasts that had a post-GC phenotype (BCL6-, MUM1+, CD138-) in the background of small lymphocytes, histiocytes, and polytypic plasma cells. Monomorphic PTLD consisted of monomorphic populations of centroblasts, immunoblasts, plasmablasts, or plasma cells, which were classified as diffuse large B-cell lymphoma (DLBCL) $(n=9)$, Burkitt lymphoma $(\mathrm{n}=1)$, marginal zone B-cell lymphoma (MZBCL) $(\mathrm{n}=1)$, and plasmacytoma-like lesion (PLL) $(\mathrm{n}=1)$. Three $(33.3 \%)$ of 9 DLBCL, all centroblastic (Fig. 1H), and the BL had a GC phenotype (BCL6+, MUM1-, CD138-) and $6(66.7 \%)$ of 9 DLBCL had a post-GC phenotype: 4 centroblastic and 1 immunoblastic (BCL6-, MUM1+, CD138-) and 1 plasmablastic (BCL6-, MUM1+, and CD138+). The MZBCL (BCL6-, MUM1+, CD138-) and PLL (BCL6-, MUM1+, CD138+) had postGC phenotypes.

\subsection{Epstein-Barr virus infection}

\subsubsection{Florid follicular hyperplasia}

The occurrence of FFH did not correlate with recent EBV infection (EBV seroconversion predated FFH by $>1$ year in all cases) and none had an IM-like illness. Epstein-Barr virus-infected lymphocytes were noted in $66.7 \% \mathrm{FFH}$ and viral reactivation was only rarely observed.

No EBER+ lymphocytes were detected in $6 \mathrm{FFH}$, and rare, single scattered EBER + small lymphocytes $(<1$ EBER + lymphocytes/10 HPF) were seen in 1 case. Increased numbers of small EBER+ lymphocytes (range, 1-54/HPF) were seen in the interfollicular areas in $11(61.1 \%)$ of $18 \mathrm{FFH}$ (Fig. 1B); large EBER+ lymphocytes were rare in all cases. Occasional EBER+ lymphocytes (range, 1-8/HPF) were seen in $2(9 \%)$ of 22 and $5(12.5 \%)$ of $40 \mathrm{GC}$ in 3 cases and numerous EBER+ cells (up to 100/HPF) were observed in $6(19.4 \%)$ of $31 \mathrm{GC}$ in 1 case. These findings are similar to previous observations in posttransplant patients [8] and healthy individuals with prior EBV infection [25].

Pre- and posttransplant IgG-VCA titers and PCR-based EBV viral load quantification data were available for $10(55.6 \%)$ of $18 \mathrm{FFH}$ patients. Six patients with FFH were EBV seronegative before transplantation (age range, 2-7 years; median, 2.5 years; mean, 3.7 years), and 4 of them seroconverted after transplantation, 1 to 4 years before development of FFH; 3 of the latter had 3 to 12 EBER+ lymphocytes/HPF in interfollicular areas, and no EBER+ lymphocytes were detected in 1 case. Four patients with FFH who were EBV seropositive pretransplantation (age range, 3-60 years; median, 5.5 years; mean, 18.5 years) showed 1 to 8 EBER+ lymphocytes/HPF in interfollicular areas; rare (1-8/HPF) EBER+ GC cells were seen in 2 cases. Viral reactivation was only observed in 2 of 10 patients by PCR (1100 and 1900 copies per milliliter) who had 3 and 9 EBER+ lymphocytes/HPF in interfollicular areas, respectively.

\subsubsection{Posttransplant lymphoproliferative disorders}

Thirteen of 20 PTLD showed evidence of EBV infection and occurrence of EBV+ PTLD showed no correlation with the patients' EBV serologic status before transplantation.

Epstein-Barr virus-positive PTLD included 4 (66.7\%) of 6 P-PTLD (Fig. 1G), 7 (58.3\%) of 12 M-PTLD, 1 IM-like lesion, and $1 \mathrm{HL}$. The IM-like lesion showed only scattered small EBER+ cells $(5 / \mathrm{HPF})$ in the interfollicular areas (Fig. 1E).

Pre- and posttransplant IgG-VCA titers were available for $12(63.2 \%)$ of 19 patients, and PCR-based EBV viral load quantification was performed in $8(50 \%)$ of 19 patients. Four patients with PTLD were EBV seronegative before transplantation (age range, 4-25 years; median, 16 years; mean, 15.3 years) and all of them seroconverted after transplantation; 2 of these patients developed $\mathrm{EBV}+$ and 2 EBV- PTLD. Of the 8 PTLD patients who were EBV seropositive before transplantation (age range, 2-72 years; median, 16 years; mean, 29.1 years), 5 developed EBV+ 
Table 2 Molecular, phenotypic, and cytogenetic characteristics of cases with karyotypic abnormalities

\begin{tabular}{|c|c|c|c|c|c|c|c|}
\hline \multirow[t]{2}{*}{ Case } & \multirow[t]{2}{*}{ Diagnosis } & \multirow[t]{2}{*}{ Phenotype } & \multirow[t]{2}{*}{ EBER } & \multirow[t]{2}{*}{ G-banded karyotype } & \multirow[t]{2}{*}{ FISH } & \multicolumn{2}{|c|}{ Clonality } \\
\hline & & & & & & PCR & $\begin{array}{l}\text { Flow } \\
\text { cytometry }\end{array}$ \\
\hline 1 & FFH & NA & Positive $^{a}$ & $46, X Y, t(1 ; 14)(q 21 ; q 32)[3] / 46, X Y[17]$ & $\operatorname{IgH} \mathrm{T}$ & $\mathrm{NC}$ & $\mathrm{P}$ \\
\hline 2 & FFH & NA & Negative & $47, \mathrm{XX},+1 \operatorname{mar}[3] / 46, \mathrm{XX}[17]$ & ND & $\mathrm{NC}$ & ND \\
\hline 3 & IM-like lesion & NA & Positive $^{\mathrm{b}}$ & $46, \mathrm{XX},-22 .+1 \mathrm{mar}[7] / 46, \mathrm{XX}[13]$ & ND & $\mathrm{NC}$ & $\mathrm{P}$ \\
\hline 4 & P-PTLD & Post-GC & Positive & $47, \mathrm{XX}, \mathrm{t}(1 ; 3)(\mathrm{p} 36 ; \mathrm{p} 21),+1 \operatorname{mar}[\mathrm{cp} 18] / 46, \mathrm{XX}[2]$ & ND & $\mathrm{C}$ & ND \\
\hline 5 & P-PTLD & Post-GC & Positive & 46,XY,ins(11;?)(q23.1;?)[3]/46,XY[9] & IgH NT, BCL6 NT & $\mathrm{NC}$ & $\mathrm{P}$ \\
\hline 6 & $\begin{array}{l}\text { M-PTLD- } \\
\text { MZBCL }\end{array}$ & Post-GC & Positive & $47, \mathrm{XY},+2, \operatorname{del}(7)(\mathrm{q} 33)[18]$ & ND & $\mathrm{C}$ & $\mathrm{P}$ \\
\hline $7 \mathrm{a}$ & $\begin{array}{l}\text { M-PTLD- } \\
\text { DLBCL, } c^{c}\end{array}$ & Post-GC & Positive $^{c}$ & $\begin{array}{l}\text { a. } 46-47, X X,+X,+2, \operatorname{add}(9)(\mathrm{p} 23), \\
-10, \operatorname{add}(16)(\mathrm{p} 13),-18 \\
+1 \operatorname{mar}[\operatorname{cp} 11] / 46, X X[1]\end{array}$ & & & \\
\hline $7 b$ & & & & $\begin{array}{l}\text { b. } 46-47, X X,+X,+2, \\
\operatorname{add}(9)(p 23)[\mathrm{cp} 9] / 46-47, X X,+X, \\
+2, \operatorname{der}(9) t(1 ; 9)(q 21 ; p 23)[\mathrm{cp} 10] / 46, X X[1]\end{array}$ & $\operatorname{IgH~NT}^{\mathrm{c}}$ & $\mathrm{NC}^{\mathrm{c}}$ & $\mathrm{C}^{\mathrm{c}}$ \\
\hline 8 & $\begin{array}{l}\text { M-PTLD- } \\
\text { DLBCL, c }\end{array}$ & GC & Negative & $48, \mathrm{XY},+\mathrm{X},+7[19] / 46, \mathrm{XY}[1]$ & IgH NT & $\mathrm{NC}$ & $\mathrm{P}$ \\
\hline 9 & $\begin{array}{l}\text { M-PTLD- } \\
\text { DLBCL, I }\end{array}$ & Post-GC & Positive & $\begin{array}{l}\text { 46,XY,del(3)(q22q24), } \\
\operatorname{der}(7) \operatorname{add}(7)(p 22) \operatorname{add}(7)(q 36)[14] / 46, X Y[6]\end{array}$ & ND & NA & ND \\
\hline 10 & $\begin{array}{l}\text { M-PTLD- } \\
\text { DLBCL, c }\end{array}$ & GC & Negative & $\begin{array}{l}\text { 54, XY, }+\mathrm{X}, \mathrm{i}(1)(\mathrm{q} 10), \mathrm{t}(2 ; 3)(\mathrm{p} 11.2 ; \mathrm{q} 27) \\
\operatorname{der}(2) \mathrm{t}(2 ; 17)(\mathrm{p} 11.2 ; \mathrm{q} 12) \\
\operatorname{der}(4) \mathrm{t}(2 ; 4)(\mathrm{p} 12 ; \mathrm{p} 15.3), \operatorname{dup}(5)(\mathrm{q} 31 \mathrm{q} 35) \\
+7,+8,+12, \operatorname{der}(14) \mathrm{t}(14 ; 14)(\mathrm{q} 13 ; \mathrm{q} 32) \\
\operatorname{der}(16) \mathrm{t}(16 ; 19)(\mathrm{q} 24 ; \mathrm{p} 12) \\
\operatorname{der}(16) \mathrm{t}(6 ; 16)(\mathrm{p} 21.2 ; \mathrm{q} 24) \\
+\operatorname{der}(16) \mathrm{t}(7 ; 16)(\mathrm{q} 22 ; \mathrm{q} 24) \\
\operatorname{der}(17) \mathrm{t}(1 ; 17)(\mathrm{p} 22 ; \mathrm{q} 21) \\
\operatorname{del}(19)(\mathrm{p} 12),+20 \times 2, \\
\operatorname{der}(21) \mathrm{t}(11 ; 21)(\mathrm{q} 13.1 ; \mathrm{p} 11.2)[7]\end{array}$ & BCL6 T, IgH NT & $\mathrm{C}$ & $P$ \\
\hline 11 & $\begin{array}{l}\text { M-PTLD- } \\
\text { DLBCL, p }\end{array}$ & post-GC & Positive & $\begin{array}{l}47, \mathrm{XY},+7, \operatorname{der}(16) \mathrm{t}(12 ; 16)(\mathrm{p} 11.2 ; \mathrm{p} 13) \\
\operatorname{der}(17) \mathrm{t}(2 ; 17)(\mathrm{q} 11.2 ; \mathrm{p} 11.2)[16] / 48 \\
\mathrm{XY}, \mathrm{idem},+1 \mathrm{mar}[4]\end{array}$ & ND & $\mathrm{C}$ & $\mathrm{C}$ \\
\hline 12 & $\begin{array}{l}\text { M-PTLD- } \\
\text { BL }\end{array}$ & GC & Negative & $\begin{array}{l}\text { 46,XY,dup(1)(q21q31.2),t(8;14)(q24;q32), } \\
\operatorname{der}(13) \mathrm{t}(1 ; 13)(\mathrm{q} 21 ; \mathrm{q} 34)[20]\end{array}$ & IgH T, MYC T & $\mathrm{C}$ & $\mathrm{C}$ \\
\hline 13 & $\begin{array}{l}\text { M-PTLD- } \\
\text { PLL }\end{array}$ & Post-GC & Negative & $\begin{array}{l}\text { 46,Y,add(X)(p22.1),t(4;16)(q25;p13.3), } \\
\operatorname{add}(18)(\mathrm{q} 21)[17] / 46, X Y[20]\end{array}$ & $\begin{array}{l}\text { IgH NT, BCL6 NT, } \\
\text { BCL2 NT, MALT1 NT }\end{array}$ & $\mathrm{C}$ & $\mathrm{C}$ \\
\hline 14 & $\mathrm{cHL}$ & NA & Positive & $\begin{array}{l}79-83,<3 \mathrm{~N}>, \mathrm{XX}, \operatorname{add}(1)(\mathrm{p} 31),+2, \\
\operatorname{dup}(3)(\mathrm{q} 13 \mathrm{q} 29 ; \mathrm{q} 13 \mathrm{q} 29) \\
-5, \operatorname{add}(5)(\mathrm{p} 15),+7, \operatorname{add}(11)(\mathrm{q} 23) \\
+12, \operatorname{add}(14)(\mathrm{p} 11) \times 2,+21, \\
-22 \times 2,+1-10 \mathrm{mar}[\mathrm{cp} 5] / 46, X X[15]\end{array}$ & ND & $\mathrm{NC}$ & ND \\
\hline
\end{tabular}

Abbreviations: NC, no clonal band obtained; P, polyclonal; C, clonal; T, translocation present; NT, no translocation detected; ND, not done; NA, not applicable.

${ }^{\text {a }}$ An average of $8 \mathrm{EBER}+$ cells/HPF were present in the interfolicular areas and 2 of $22 \mathrm{GC}$ had 2 to 8 EBER+ cells/HPF.

${ }^{\mathrm{b}}$ Only scattered (5/HPF) EBER+ cells were seen in interfollicular areas.

${ }^{c}$ Same results for both specimens.

PTLD (including an early lesion) and 3 EBV - PTLD. Viral reactivation was not observed in any patient, where data were available. The mean time from transplant to development of EBV - PTLD was longer than that of EBV+ PTLD (102.7 versus 60.6 months, $P=.11$ ), as previously reported [2], although the difference was not statistically significant.

\subsection{B-Cell clonality}

Fifteen (78.9\%) of 19 PTLD tested, including 5 (83.3\%) of 6 P-PTLD and 10 (90.9\%) of 11 M-PTLD, had evidence of a clonal B-cell population, 7 of 15 by flow cytometry and 10 of 18 by PCR for IgH gene rearrangement. None of the FFH cases showed a clonal product by PCR or light chain restriction by flow cytometry.

\subsection{G-Banded karyotype, FISH, and SKY analysis}

Fifteen (83.3\%) of $18 \mathrm{FFH}$ with analyzable metaphases had a normal karyotype, 2 (11.1\%) had clonal karyotypic abnormalities (Table 2), and $1(5.6 \%)$ had a nonclonal translocation $\mathrm{t}(7 ; 11)(\mathrm{q} 31.2 ; \mathrm{q} 24)$. In 1 patient (no. 1), the 


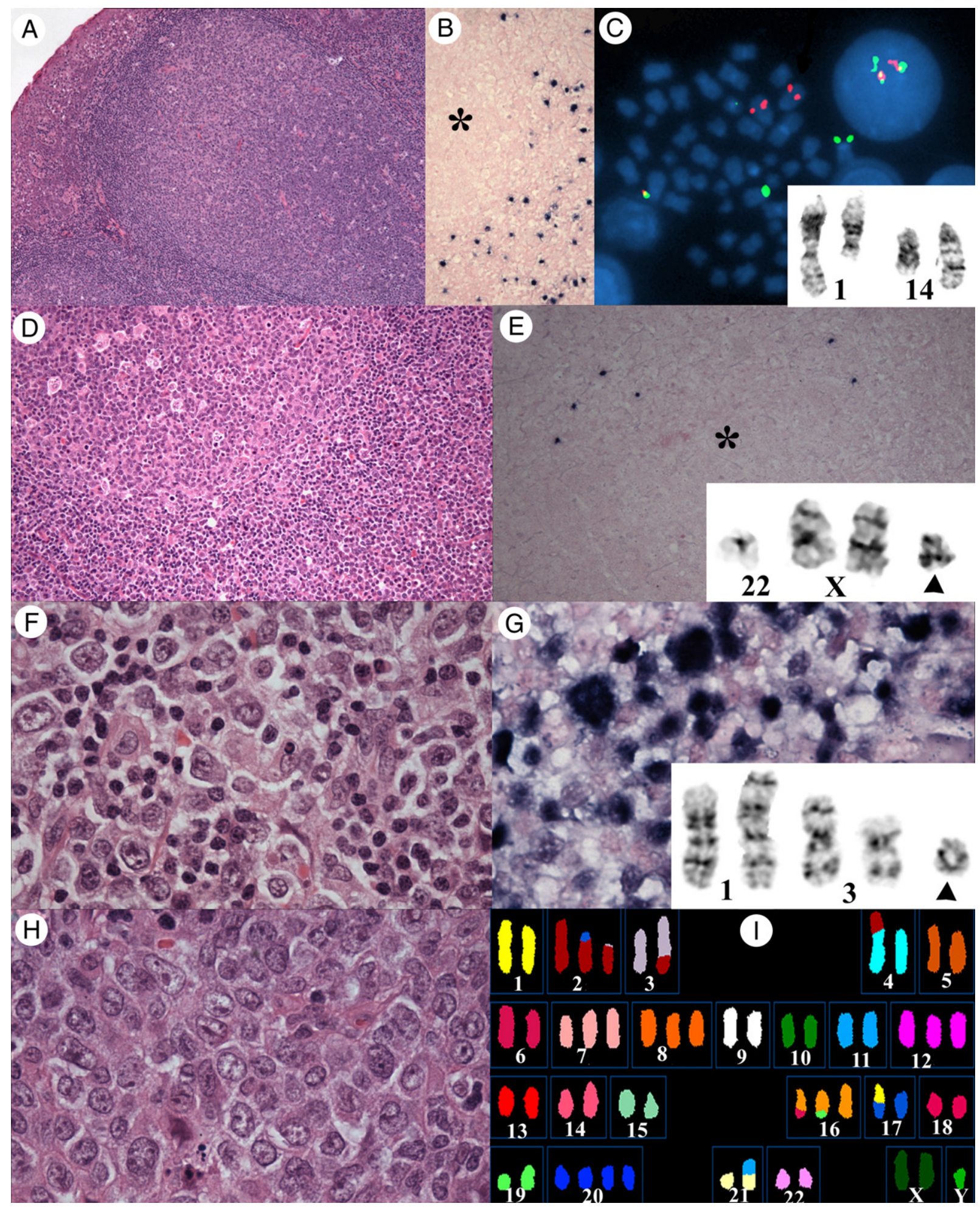

Fig. 1 Examples of posttransplant lymphoproliferations with karyotypic abnormalities. Florid follicular hyperplasia of tonsil (case 1, Table 2): expanded GC with attenuated mantle zone (A), scattered EBER+ cells are present in interfollicular areas (asterisk indicates GC) (B), FISH with IGH break-apart probe shows a metaphase spread with 2 red and green (split) signals consistent with a biallelic translocation (C), partial G-banded karyotype (C, inset) shows $\mathrm{t}(1 ; 14)(\mathrm{q} 21$; q32). Infectious mononucleosis-like lesion in tonsil (case 3, Table 2): expanded GC and interfollicular areas (D), rare EBER+ cells are seen in interfollicular areas (asterisk indicates GC) (E), partial G-banded karyotype (E, inset) shows loss of 1 copy of chromosome 22 and presence of a marker chromosome (arrowhead). Polymorphic PTLD (case 4): scattered large centroblast-like cells amidst plasma cells, small lymphocytes, and histiocytes (F), which are EBER+ (G); partial G-banded karyotype $(\mathrm{G}$, inset) shows $\mathrm{t}(1 ; 3)(\mathrm{p} 36 ; \mathrm{p} 21)$ and a marker chromosome (arrowhead). Monomorphic PTLD (DLBCL) (case 10, Table 2) with centroblastic morphology (H): SKY (I) shows complex karyotypic abnormalities, including t(2;3)(p11.2;q27). 
same karyotypic abnormality was detected in the adenoids and tonsils.

Normal karyotypes were observed in 7 (35\%) of 20 PTLD with analyzable metaphases, including $3(25 \%)$ of 12 M-PTLD and $4(66.7 \%)$ of 6 P-PTLD. Clonal karyotypic abnormalities were detected in $13(65 \%)$ of 20 PTLD, including 9 (75\%) of 12 M-PTLD, 2 (33.3\%) of 6 P-PTLD (Fig. 1G), 1 of 1 IM-like lesion (Fig. 1E), and 1 of $1 \mathrm{HL}$ (Table 2). All P-PTLD, FFH, and the IM-like lesion exhibited simple $(<3)$ karyotypic abnormalities, whereas $2(22.2 \%)$ of 9 M-PTLD had simple karyotypic abnormalities and 7 (77.8\%) of 9 M-PTLD and the HL had complex karyotypes.

A total of 100 chromosome aberrations (Fig. 2) were found, which include 78 structural abnormalities (4.9 breakpoints per case, each marker chromosomes representing 2 breakpoints) and 22 numerical abnormalities (1.4 per case). Of the numerical abnormalities, gain of chromosomes

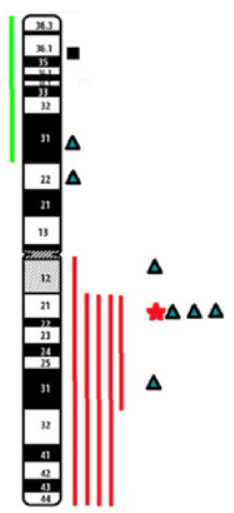

1

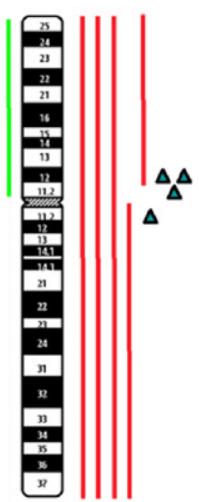

2
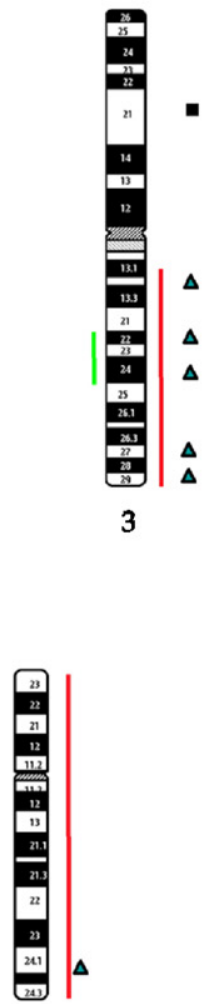

8

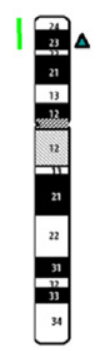

9

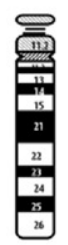

15

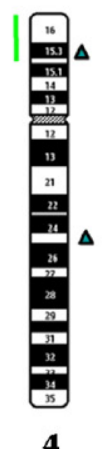

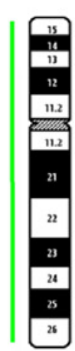

10

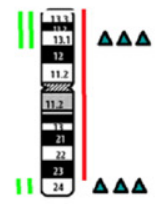

16

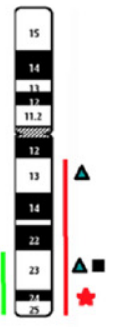

11

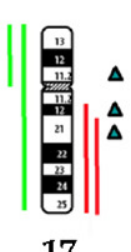

17

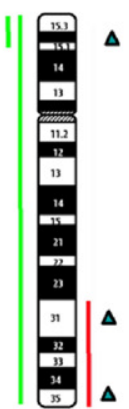

5

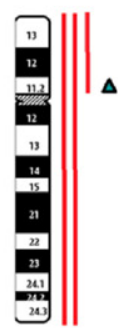

12
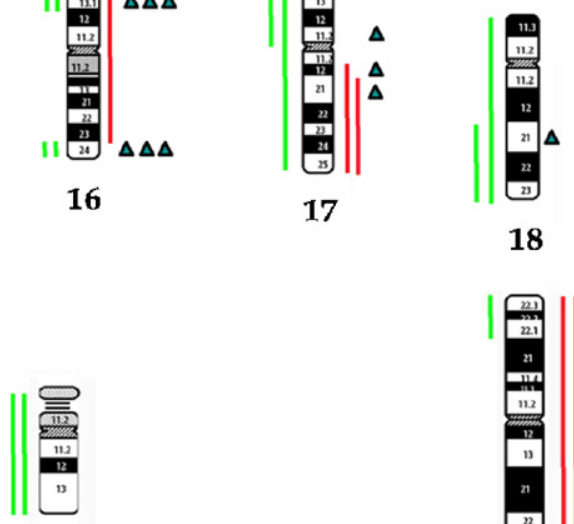

22

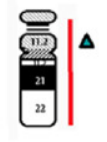

21

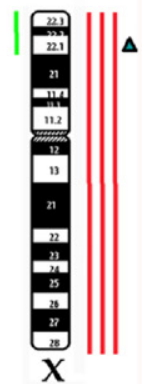

Fig. 2 Chromosome ideograms illustrating genomic aberrations in the various types of posttransplant lymphoproliferations. Each line represents a gain (red) or loss (green) of chromosomes or chromosomal regions (stars, squares, and triangles denote breakpoints in FFH, PPTLD, and M-PTLD, respectively). 
was more frequent $(\mathrm{n}=15)$ than loss $(\mathrm{n}=7)$. Trisomy 7 $(\mathrm{n}=4), X(\mathrm{n}=3), 2(\mathrm{n}=3)$, and $12(\mathrm{n}=2)$ were recurrent chromosome gains, whereas chromosome $22(\mathrm{n}=2)$ was the only recurrently lost chromosome. In addition, a complete or partial gain of 1q region was observed in 5 cases. Of the clonal structural abnormalities, chromosome breaks involving the 1q11-q21 region were the most frequent $(\mathrm{n}=6$, including $1 \mathrm{FFH})$, followed by $16 \mathrm{p} 13$ $(\mathrm{n}=3), 14 \mathrm{q} 32(\mathrm{n}=3$, including $1 \mathrm{FFH})$, and 11q23-24 $(\mathrm{n}=2)$. Nonrecurrent translocation breaks at $3 \mathrm{q} 27$ and $18 \mathrm{q} 21$ were seen in 1 case each.

Fluorescence in situ hybridization analysis using a variety of break-apart probes was performed in 14 cases (6 with abnormal karyotypes, 6 with normal karyotypes, and 2 with no analyzable metaphases). Fluorescence in situ hybridization analysis using the IGH probe confirmed translocation of this locus in 2 of 3 cases with $14 \mathrm{q} 32$ translocations, including a biallelic translocation in $1 \mathrm{FFH}$ (Fig. 1C). Ten additional cases tested, including 2 cases without analyzable metaphases, did not show IGH translocations. In 1 M-PTLD with a $3 \mathrm{q} 27$ translocation, FISH analysis using the $B C L 6$ probe confirmed translocation of BCL6; no abnormalities were detected in 4 other cases, including 1 case without analyzable metaphases. Fluorescence in situ hybridization analysis using the $B C L 2$ probe did not show translocation of this gene in 3 cases, including 1 case with an add(18)(q21) marker chromosome. The latter was also negative for MALT1 translocation. Fluorescence in situ hybridization analysis using the $M Y C$ probe showed translocation in $2 \mathrm{BL}$ tested including 1 without analyzable metaphases.

Ten of 16 lymphoproliferations with abnormal karyotypes by G-banding had some unidentifiable karyotypic changes and/or marker chromosomes. Spectral karyotype analysis was performed on 2 such PTLD (patients 10 and 11) in an attempt to identify uncharacterized aberrations. Spectral karyotype analysis identified add(16)(p13), seen on G-banding in 1 M-PTLD case (no. 11), as $\operatorname{der}(16) \mathrm{t}$ $(12 ; 16)(\mathrm{p} 11.2 ; \mathrm{p} 13)$; however, a marker chromosome seen in a small subclone could not be identified because of lack of additional metaphases with this abnormality. Another M-PTLD (patient 10) showed a highly complex karyotype by G-banding: $54, \mathrm{XY},+\mathrm{X}, \mathrm{t}(1 ; 4)(\mathrm{q} 12 ; \mathrm{p} 15.3),+\mathrm{i}(1)(\mathrm{q} 10)$, $\mathrm{t}(2 ; 3)(\mathrm{p} 11.2 ; \mathrm{q} 27), \operatorname{add}(2)(\mathrm{p} 11.2), \operatorname{dup}(5)(\mathrm{q} 31 \mathrm{q} 35)$, $+7,+8,+12, \operatorname{der}(14) \mathrm{t}(14 ; 14)(\mathrm{q} 13 ; \mathrm{q} 21), \operatorname{add}(16)(\mathrm{q} 21), \operatorname{add}(16)$ $(\mathrm{q} 22),+\operatorname{add}(16)(\mathrm{q} 23),-17,-19,+20 \times 2, \operatorname{der}(21) \mathrm{t}(11 ; 21)$ (q13.1;p11.2),+22[15]. Many of the markers that could not be characterized by G-banding were identified by SKY analysis (Fig. 1I, modified SKY karyotype is shown in Table 2).

\subsection{Correlation of cytogenetic abnormalities with EBV infection, phenotype, B-cell clonality, and clinical outcome}

There was no significant association between EBV infection and the presence of karyotypic aberrations in
Table 3 Correlation of PTLD cytogenetic abnormalities with EBV infection, phenotype, clonality, clinical outcome, and time since transplant

\begin{tabular}{|c|c|c|c|}
\hline \multirow[t]{2}{*}{ Parameter } & \multicolumn{2}{|l|}{ Karyotype } & \multirow{2}{*}{$\begin{array}{l}P, \text { abnormal } \\
\text { karyotype } \\
\text { (complex } \\
\text { karyotype) }\end{array}$} \\
\hline & $\begin{array}{l}\text { Abnormal, total } \\
\text { (complex) }\end{array}$ & Normal & \\
\hline \multicolumn{4}{|l|}{ EBV infection } \\
\hline EBER+ & $\mathrm{n}=9(\mathrm{n}=5)$ & $\mathrm{n}=4$ & $.65(1)$ \\
\hline EBER - & $\mathrm{n}=4(\mathrm{n}=3)$ & $\mathrm{n}=3$ & \\
\hline EBV seropositive $^{\mathrm{a}}$ & $\mathrm{n}=5(\mathrm{n}=4)$ & $\mathrm{n}=3$ & $1(1)$ \\
\hline EBV seronegative ${ }^{a}$ & $\mathrm{n}=4(\mathrm{n}=4)$ & $\mathrm{n}=1$ & \\
\hline \multicolumn{4}{|l|}{ Phenotype } \\
\hline $\mathrm{GC}$ & $\mathrm{n}=3(\mathrm{n}=2)$ & $\mathrm{n}=1$ & $1(1)$ \\
\hline Post-GC & $\mathrm{n}=8(\mathrm{n}=5)$ & $\mathrm{n}=6$ & \\
\hline \multicolumn{4}{|l|}{ Clonality } \\
\hline Clonal $^{\mathrm{b}}$ & $\mathrm{n}=8(\mathrm{n}=6)$ & $\mathrm{n}=7$ & $.24(0.22)$ \\
\hline $\begin{array}{l}\text { No evidence } \\
\text { of clonality }\end{array}$ & $\mathrm{n}=4(\mathrm{n}=1)$ & $\mathrm{n}=0$ & \\
\hline \multicolumn{4}{|l|}{ Clinical outcome } \\
\hline Dead & $\mathrm{n}=4(\mathrm{n}=3)$ & $\mathrm{n}=4$ & $.38(0.58)$ \\
\hline Alive & $\mathrm{n}=8(\mathrm{n}=4)$ & $\mathrm{n}=3$ & \\
\hline $\begin{array}{l}\text { Time since } \\
\text { transplant }\end{array}$ & $\begin{array}{l}75.6 \mathrm{mo} \\
(93.6 \mathrm{mo})\end{array}$ & $53.4 \mathrm{mo}$ & $.04(0.76)$ \\
\hline
\end{tabular}

FFH. Cytogenetic abnormalities were present in EBERand EBER+ FFH (1/7 [14.3\%] versus 1/11 [9.1\%], $P=1.0)$ and occurred in both patients who were EBV seropositive or seronegative before transplantation (1/4 [25\%] versus $1 / 6$ $[16.7 \%], P=1.0)$. Posttransplant lymphoproliferative disorders with chromosomal abnormalities occurred significantly later posttransplant compared to those with normal karyotypes (Table 3) and 14q32 abnormalities were only seen in PTLD with a GC phenotype ( $2 / 3 \mathrm{GC}$ versus $0 / 8$ postGC, $P=.05$ ). Although $16 \mathrm{p} 13$ abnormalities were only found in PTLD with a post-GC phenotype, the results did not reach statistical significance $(0 / 3 \mathrm{GC}$ versus $3 / 8$ postGC, $P=.49$ ), presumably because of the small sample size. Overall, the presence (or complexity) of cytogenetic abnormalities did not correlate with EBV infection, phenotype, clonality, or clinical outcome (Table 3). Of interest, clonal chromosomal abnormalities were detected in 4 PTLD (1 IM-like lesion, $1 \mathrm{HL}, 1 \mathrm{P}-\mathrm{PTLD}, 1 \mathrm{M}-\mathrm{PTLD})$ that were polyclonal by flow cytometry and/or did not show a clonal band by PCR analysis, highlighting the utility of cytogenetic analysis in detecting clonal proliferations in PTLD.

\section{Discussion}

Infectious mononucleosis-like lesions and $\mathrm{PH}$ are considered the earliest morphologically recognizable types of PTLD in the current WHO classification [1], as both P-PTLD and M-PTLD have been documented in the vicinity of or at another site concurrently or subsequent to such 
lymphoproliferations [26,27]. One of our patients with $\mathrm{PH}$ also developed an M-PTLD (PLL) at the same site. However, in the absence of any demonstrable increase in risk for developing more advanced PTLD, some have argued against inclusion of these lesions as forms of PTLD [5]; an argument perhaps bolstered by the absence of mutations and/or translocations of oncogenes or tumor suppressor genes in patients with $\mathrm{PH}$ [4]. Epstein-Barr virus infection has been implicated in the pathogenesis of IM-like lesions and PH [4,27], although EBV - IM-like lesions have been described [2]. The presence of rare EBER+ cells in our IMlike lesion could possibly be attributed to the immunosuppressed state, suggesting an etiology similar to EBV - cases. The detection of a clonal aberration in an IM-like lesion, which has also been observed in other types of PTLD, often in association with other abnormalities (see below) [21,22], illustrates that genetic aberrations do occur in IM-like lesions and supports the contention of including these lesions within the spectrum of PTLD.

Lymphoid tissue of the Waldeyer's ring is a common site for FFH [6,7] and PTLD [26], especially in children, which has been attributed to a greater frequency of primary EBV infection in these patients. Adenotonsillar FFH has been proposed to represent an early event in PTLD pathogenesis $[6,7]$; however, no PTLD were observed within a period of 5 years after FFH in one study [8]. In our study, 2 patients developed PTLD after previous FFH. Although clonal relatedness between FFH and PTLD could not be demonstrated, the occurrence of early lesions or other types of PTLD in the vicinity of prior FFH suggests that FFH could represent the earliest phase of immune activation, which can progress to more advanced types of PTLD, albeit in a minority of patients and after a long latency period. This hypothesis is supported by the report of Lones et al [26] who described a tonsillar P-PTLD that developed in the background of FFH. The occurrence of FFH at the same or different site, after PTLD in 2 of our patients, does not argue against this proposal, as multiple metachronous PTLD arising at different sites are not uncommon in transplant patients [27] and FFH could conceivably be the precursor of these lymphoproliferations.

We did not find any correlation between EBV infection and the occurrence of FFH in our patients, suggesting that FFH posttransplantation is a consequence of chronic antigenic stimulation in the setting of immune deregulation rather than EBV infection per se. The occurrence of EBVPTLD in EBV-seropositive individuals also supports an important primary role of immune deregulation in the pathogenesis of PTLD. Minor clonal karyotypic abnormalities were identified in $11.1 \%$ of cases of FFH, possibly arising during florid GC reactions. Similar abnormalities have also been reported in P-PTLD [18,22] and M-PTLD [19-22], further supporting a pathogenetic link between FFH and more advanced forms of PTLD. It has been shown that synchronous or metachronous PTLD, involving the same organ or occurring at different sites, can either represent different, distinct clonal proliferations [28] or migration of the same neoplastic clone [29]. However, the time of clonal spread is not known. Our detection of identical cytogenetic abnormalities in the tonsils and adenoids of 1 patient with FFH indicated local dissemination of the abnormal clone, which leads us to speculate that (at least) regional spread of aberrant clones might occur early in the evolution of some PTLD.

Cytogenetic abnormalities were also observed in $65 \%$ of our B-cell PTLD (33\% of P-PTLD and 75\% of M-PTLD), a higher overall frequency compared to the reports of Poirel et al [21], who found chromosomal imbalances in $48 \%$ of B-cell PTLD (57\% of P-PTLD and 46\% of M-PTLD) using comparative genomic hybridization analysis and Djokic et al [22], who identified chromosomal abnormalities in $45 \%$ of Bcell PTLD (15\% of P-PTLD and $72 \%$ of M-PTLD) by G-banded karyotype analysis. Poirel et al reported a tendency for EBV- PTLD to have more complex chromosomal abnormalities compared with EBV+ PTLD and a worse clinical outcome of M-PTLD with cytogenetic abnormalities. We did not observe a difference in the cytogenetic complexity between EBV - or EBV+ PTLD or in the clinical outcomes of patients with PTLD associated with cytogenetic abnormalities compared with patients who had PTLD with normal karyotypes. This might relate to shorter follow-up, fewer EBV - PTLD, differences in therapy, or most likely an absence of T-cell PTLD in our series. The latter are more often EBV - and have a more aggressive clinical course [30].

Posttransplant lymphoproliferative disorders with karyotypic abnormalities in our series occurred significantly later compared with those lacking cytogenetic aberrations (Table 3). Failure to obtain metaphases from neoplastic lymphocytes could have accounted for the normal karyotype in some of our PTLD. However, an absence of chromosomal imbalances in $52 \%$ of PTLD by comparative genomic hybridization analysis [21] suggests that subsets of PTLD could arise by mutations or epigenetic alterations of oncogenes and tumor suppressor genes or cellular transformation by oncogenic EBV latency proteins in certain cases $[15,31,32]$.

A few of the karyotypic abnormalities observed in our PTLD, including the IM-like lesion, have been previously reported [16,18-22], although the frequency of various recurrent abnormalities in our series (chromosomes 1q and 7) differed from those described by Poirel et al [21] (8q24 and 3q gains) and Djokic et al [22] (trisomy 9 and 11). Epstein-Barr virus-associated PTLD with chromosome 9 and 11 aberrations have also been described by others $[3,18,20]$ and Thangavelu et al [33] detected trisomy 9 and 11 among other clonal abnormalities in B-cell lymphomas that developed in severe combined immunodeficiency mice inoculated with lymphocytes from EBV seropositive individuals. We only observed insertions or translocations targeting chromosomal region 11q23-q24 in 1 case each of P-PTLD, and HL and 9p23 in 1 case of M-PTLD. Of interest, chromosome $14 \mathrm{q} 32$ aberrations were only seen in 
PTLD with a GC phenotype and 16p13 abnormalities in PTLD with a post-GC phenotype. Translocations of $M Y C$ were detected in BL similar to the reports of Djokic et al [22] and Nelson et al [2] but not in other types of M-PTLD [21]. Translocations of 3q27 (BCL6) and 18q21 were rare in our series, consistent with previous reports $[2,4,16,21,22]$.

All the chromosomal abnormalities observed in our cases of FFH and PTLD have also been described in a variety of B-NHL occurring in immunocompetent patients [9-13], and many of the loci involved, including 1q21, 1p36, 3p21, $9 \mathrm{p} 23$, and $16 \mathrm{p} 13$, are thought to harbor potential oncogenes or tumor suppressor genes [34-38]. Our findings, however, highlight differences between PTLD and B-NHL of immunocompetent individuals. Karyotypic aberrations in M-PTLD, with few exceptions, were less complex compared to DLBCL of immunocompetent individuals [10,11], and besides $\mathrm{BL}$, cytogenetic abnormalities associated with distinct subsets of B-NHL were rarely observed. No translocation $\mathrm{t}(14 ; 18)$ was detected. Gains of chromosomes $\mathrm{X}, 2,7$, and 12, and chromosome 1q21 aberrations, considered common secondary alterations in conventional B-NHL $[11,12,39,40]$, were either present as isolated abnormalities or seen in conjunction with few additional karyotypic aberrations in our PTLD. Moreover, an inferior outcome for PTLD with trisomy 7 or 12 and chromosome 1q21 abnormalities could not be discerned, contrary to what has been reported for conventional DLBCL $[12,13]$. Our findings, in addition to prior observations [20,22], suggest an early acquisition of the aforementioned abnormalities in PTLD and indicate differences in the pathways of cytogenetic progression of these lymphoproliferations compared to conventional B-NHL.

DNA double-strand break repair after somatic hypermutation and class-switch recombination during the GC reaction, thought to be responsible for chromosome translocations in B-NHL [41], might also lead to chromosomal translocations in PTLD. In vitro infection of lymphocytes by EBV has been shown to induce chromosomal missegregration resulting in numerical and structural chromosomal abnormalities $[42,43]$, possibly due to genetic instability of adjacent sites of EBV integration or as a consequence of oxidative stress $[44,45]$. We did not identify any consistent or unique chromosomal aberrations in EBV+ PTLD; however, further studies are warranted to investigate whether chromosomal abnormalities in certain PTLD are the consequence of a "hit-and-run" mechanism of EBV infection [46] or EBV integration.

In summary, we not only confirm previously reported cytogenetic abnormalities but also describe novel karyotypic abnormalities in PTLD. Our data expand the spectrum of chromosomal aberrations associated with these disorders, which should serve as a useful adjunct to future whole genome analyses. The presence of karyotypic abnormalities was not associated with a worse prognosis and the sequence of acquisition of chromosomal aberrations in PTLD appeared different compared to conventional DLBCL. We also report karyotypic abnormalities in FFH and early lesions, which have not been described previously. Our findings provide cytogenetic validation of the current WHO classification of PTLD and suggest incorporation of FFH as the earliest precursor in the stepwise model of PTLD pathogenesis.

\section{References}

[1] Harris N, Swerdlow S, Frizzera G, Knowles D. Post-transplant lymphoproliferative disorders. In: Jaffe E, Harris N, Vardiman J, editors. Tumours of haematopoietic and lymphoid tissues. Lyon: International Agency for Research on Cancer; 2001. p. 264-9.

[2] Nelson BP, Nalesnik MA, Bahler DW, Locker J, Fung JJ, Swerdlow SH. Epstein-Barr virus-negative post-transplant lymphoproliferative disorders: a distinct entity? Am J Surg Pathol 2000;24:375-85.

[3] Frizzera G, Hanto DW, Gajl-Peczalska KJ, et al. Polymorphic diffuse B-cell hyperplasias and lymphomas in renal transplant recipients. Cancer Res 1981;41(11 Pt 1):4262-79.

[4] Knowles DM, Cesarman E, Chadburn A, et al. Correlative morphologic and molecular genetic analysis demonstrates three distinct categories of posttransplantation lymphoproliferative disorders. Blood 1995;85:552-65

[5] Nalesnik MA, Jaffe R, Starzl TE, et al. The pathology of posttransplant lymphoproliferative disorders occurring in the setting of cyclosporine A-prednisone immunosuppression. Am J Pathol 1988; 133:173-92.

[6] Shapiro NL, Strocker AM, Bhattacharyya N. Risk factors for adenotonsillar hypertrophy in children following solid organ transplantation. Int J Pediatr Otorhinolaryngol 2003;67:151 - 5.

[7] Williamson RA, Huang RY, Shapiro NL. Adenotonsillar histopathology after organ transplantation. Otolaryngol Head Neck Surg 2001; 125:231-240.

[8] Meru N, Davison S, Whitehead L, et al. Epstein-Barr virus infection in paediatric liver transplant recipients: detection of the virus in posttransplant tonsillectomy specimens. Mol Pathol 2001;54:264-9.

[9] Fan YS, Rizkalla K. Comprehensive cytogenetic analysis including multicolor spectral karyotyping and interphase fluorescence in situ hybridization in lymphoma diagnosis. A summary of 154 cases. Cancer Genet Cytogenet 2003;143:73-9.

[10] Cigudosa JC, Parsa NZ, Louie DC, et al. Cytogenetic analysis of 363 consecutively ascertained diffuse large B-cell lymphomas. Genes Chromosomes Cancer 1999;25:123 - 33 .

[11] Martinez-Climent JA, Alizadeh AA, Segraves R, et al. Transformation of follicular lymphoma to diffuse large cell lymphoma is associated with a heterogeneous set of DNA copy number and gene expression alterations. Blood 2003;101:3109-17.

[12] Offit K, Wong G, Filippa DA, Tao Y, Chaganti RS. Cytogenetic analysis of 434 consecutively ascertained specimens of non-Hodgkin's lymphoma: clinical correlations. Blood 1991;77:1508 - 15 .

[13] Whang-Peng J, Knutsen T, Jaffe ES, et al. Sequential analysis of 43 patients with non-Hodgkin's lymphoma: clinical correlations with cytogenetic, histologic, immunophenotyping, and molecular studies. Blood 1995;85:203-16.

[14] Cesarman E, Chadburn A, Liu YF, Migliazza A, Dalla-Favera R, Knowles DM. BCL-6 gene mutations in posttransplantation lymphoproliferative disorders predict response to therapy and clinical outcome. Blood 1998;92:2294-302.

[15] Cerri M, Capello D, Muti G, et al. Aberrant somatic hypermutation in post-transplant lymphoproliferative disorders. Br J Haematol 2004; 127:362-4

[16] Delecluse HJ, Rouault JP, Jeammot B, Kremmer E, Bastard C, Berger F. Bcl6/Laz3 rearrangements in post-transplant lymphoproliferative disorders. Br J Haematol 1995;91:101-3. 
[17] Delecluse HJ, Rouault JP, Ffrench M, Dureau G, Magaud JP, Berger F. Post-transplant lymphoproliferative disorders with genetic abnormalities commonly found in malignant tumours. Br J Haematol 1995; 89:90-7.

[18] Dunphy CH, Batanian JR. A clinically aggressive, polymorphic, polyclonal posttransplantation lymphoproliferative disorder. Cancer Genet Cytogenet 1998;106:49-53.

[19] Fasan O, Willmott C, Czepulkowski B, et al. Epstein-Barr virusrelated post-transplant lymphoproliferative disorder with $\mathrm{t}(9 ; 14)(\mathrm{p} 11-$ 12;q32). Cancer Genet Cytogenet 2003;142:134-6.

[20] Cabanillas F, Pathak S, Zander A, et al. Monosomy 21, partial duplication of chromosome 11, and structural abnormality of chromosome 1q21 in a case of lymphoma developing in a transplant recipient: characteristic abnormalities of secondary lymphoma? Cancer Genet Cytogenet 1987;24:7-10.

[21] Poirel HA, Bernheim A, Schneider A, et al. Characteristic pattern of chromosomal imbalances in posttransplantation lymphoproliferative disorders: correlation with histopathological subcategories and EBV status. Transplantation 2005;80:176-84.

[22] Djokic M, LeBeau MM, Swinnen LJ, et al. Post-transplant lymphoproliferative disorder subtypes correlate with different recurring chromosomal abnormalities. Genes Chromosomes Cancer 2006;45: $13-8$.

[23] Sioutos N, Bagg A, Michaud GY, et al. Polymerase chain reaction versus Southern blot hybridization. Detection of immunoglobulin heavy-chain gene rearrangements. Diagn Mol Pathol 1995;4:8 - 13.

[24] Shaffer L, Tommerup N, editors. An international system for human cytogenetic nomenclature. Basel: S. Karger; 2005.

[25] Niedobitek G, Herbst H, Young LS, et al. Patterns of Epstein-Barr virus infection in non-neoplastic lymphoid tissue. Blood 1992; 79:2520-6.

[26] Lones MA, Mishalani S, Shintaku IP, Weiss LM, Nichols WS, Said JW. Changes in tonsils and adenoids in children with posttransplant lymphoproliferative disorder: report of three cases with early involvement of Waldeyer's ring. HUM PATHOL 1995;26:525 - 30.

[27] Wu TT, Swerdlow SH, Locker J, et al. Recurrent Epstein-Barr virusassociated lesions in organ transplant recipients. HUM PATHOL 1996;27:157-64.

[28] Chadburn A, Cesarman E, Liu YF, et al. Molecular genetic analysis demonstrates that multiple posttransplantation lymphoproliferative disorders occurring in one anatomic site in a single patient represent distinct primary lymphoid neoplasms. Cancer 1995;75: 2747-56.

[29] Kaplan MA, Ferry JA, Harris NL, Jacobson JO. Clonal analysis of posttransplant lymphoproliferative disorders, using both episomal Epstein-Barr virus and immunoglobulin genes as markers. Am J Clin Pathol 1994;101:590-6.

[30] Draoua HY, Tsao L, Mancini DM, Addonizio LJ, Bhagat G, Alobeid B. T-cell post-transplantation lymphoproliferative disorders after cardiac transplantation: a single institutional experience. $\mathrm{Br} \mathrm{J}$ Haematol 2004;127:429-32.
[31] Rossi D, Gaidano G, Gloghini A, et al. Frequent aberrant promoter hypermethylation of $O^{6}$-methylguanine-DNA methyltransferase and death-associated protein kinase genes in immunodeficiency-related lymphomas. Br J Haematol 2003;123:475-8.

[32] Kuppers R. B cells under influence: transformation of B cells by Epstein-Barr virus. Nat Rev Immunol 2003;3:801 - 12.

[33] Thangavelu M, Snyder L, Anastasi J, et al. Cytogenetic characterization of B-cell lymphomas from severe combined immunodeficiency disease mice given injections of lymphocytes from Epstein-Barr virus-positive donors. Cancer Res 1992;52:4678-81.

[34] Itoyama T, Nanjungud G, Chen W, et al. Molecular cytogenetic analysis of genomic instability at the 1q12-22 chromosomal site in Bcell non-Hodgkin lymphoma. Genes Chromosomes Cancer 2002; $35: 318-28$.

[35] Stoffel A, Filippa D, Rao PH. The p73 locus is commonly deleted in non-Hodgkin's lymphomas. Leuk Res 2004;28:1341-5.

[36] Tommasi S, Dammann R, Zhang Z, et al. Tumor susceptibility of Rassfla knockout mice. Cancer Res 2005;65:92-8.

[37] Yoshida S, Kaneita Y, Aoki Y, Seto M, Mori S, Moriyama M. Identification of heterologous translocation partner genes fused to the BCL6 gene in diffuse large B-cell lymphomas: $5^{\prime}$-RACE and LAPCR analyses of biopsy samples. Oncogene 1999;18:7994-9.

[38] Joos S, Kupper M, Ohl S, et al. Genomic imbalances including amplification of the tyrosine kinase gene JAK2 in CD30+ Hodgkin cells. Cancer Res 2000;60:549-52.

[39] Bernell P, Jacobsson B, Liliemark J, Hjalmar V, Arvidsson I, Hast R. Gain of chromosome 7 marks the progression from indolent to aggressive follicle centre lymphoma and is a common finding in patients with diffuse large B-cell lymphoma: a study by FISH. Br J Haematol 1998;101:487-91.

[40] McDonald HL, Gascoyne RD, Horsman D, Brown CJ. Involvement of the $\mathrm{X}$ chromosome in non-Hodgkin lymphoma. Genes Chromosomes Cancer 2000;28:246-57.

[41] Kuppers R, Dalla-Favera R. Mechanisms of chromosomal translocations in B cell lymphomas. Oncogene 2001;20:5580-94.

[42] Okubo M, Tsurukubo Y, Higaki T, et al. Clonal chromosomal aberrations accompanied by strong telomerase activity in immortalization of human B-lymphoblastoid cell lines transformed by EpsteinBarr virus. Cancer Genet Cytogenet 2001;129:30-4.

[43] Gerber P, Whang-Peng J, Monroe J. Transformation and chromosome changes induced by Epstein-Barr virus in normal human leukocytes in cultures. Proc Natl Acad Sci U S A 1969;63:740-7.

[44] Gualandi G, Giselico L, Carloni M, Palitti F, Mosesso P, Alfonsi AM. Enhancement of genetic instability in human B cells by Epstein-Barr virus latent infection. Mutagenesis 2001;16:203-8.

[45] Wolf J, Jox A, Skarbek H, et al. Selective loss of integrated EpsteinBarr virus genomes after long-term cultivation of Burkitt's lymphoma $\times$ B-lymphoblastoid cell hybrids due to chromatin instability at the integration site. Virology 1995;212:179-85.

[46] Ambinder RF. Gammaherpes viruses and "hit-and-run" oncogenesis. Am J Pathol 2000;156:1 -3. 